\title{
EVALUASI PROGRAM PENGEMBANGAN SAPI POTONG GADUHAN MELALUI KELOMPOK LEMBAGA MANDIRI YANG MENGAKAR DI MASYARAKAT DI KABUPATEN MANOKWARI PAPUA BARAT
}

\section{EVALUATION OF CATTLE SHARING SYSTEM IN THE DEVELOPMENT OF CATTLE FARMING FOR THE FARMER GROUPS UNDER LEMBAGA MANDIRI YANG MENGAKAR DI MASYARAKAT IN MANOKWARI REGENCY WEST PAPUA}

\author{
Lukas Yowel Sonbait ${ }^{1 *}$, Krishna Agung Santosa ${ }^{2}$, dan Panjono ${ }^{2}$ \\ ${ }^{1}$ Fakultas Peternakan, Perikanan dan Ilmu Kelautan, Universitas Negeri Papua, Jl. Gunung Salju, Amban, Manokwari - \\ Papua Barat, 98314 \\ ${ }^{2}$ Fakultas Peternakan, Universitas Gadjah Mada, Jl. Fauna No. 3, Bulaksumur, Yogyakarta, 55281
}

\section{INTISARI}

Penelitian bertujuan untuk mengevaluasi program pengembangan sapi potong gaduhan melalui kelompok Lembaga Mandiri yang Mengakar di Masyarakat (LM3), yang merupakan sebuah lembaga mandiri berbasis masyarakat di Manokwari, Papua Barat, ditinjau dari pendapatan peternak dari usaha sapi potong, penyerapan tenaga kerja dan kenaikan populasi sapi potong. Survei dilakukan terhadap seluruh peserta program gaduhan sebanyak 55 peternak yang berlangsung sejak bulan Agustus sampai Oktober 2010. Net present value (NPV), benefit cost ratio (BCR) dan internal rate return (IRR) dihitung dari kondisi sebelum dan setelah mengikuti program. Nilai NPV meningkat sebesar 64,40\% dari Rp. 18.251.432,00 menjadi Rp. 28.338.774,00. Nilai BCR dan IRR berturut-turut adalah 21,35 dan 50\%. Rerata pendapatan diperoleh sebesar Rp. 5.212.500,00 per tahun. Kenaikan populasi sapi potong secara alami adalah sebesar $27,05 \%$ per tahun. Program gaduhan mampu meningkatkan penyerapan tenaga kerja sebesar 12,27\%. Analisis regresi menunjukkan bahwa faktor yang berpengaruh terhadap waktu pengembalian oleh peternak adalah angka mortalitas $(\mathrm{P}<0,01)$, pengalaman beternak $(\mathrm{P}<0,05)$ dan calving interval $(\mathrm{P}<0,01)$. Kesimpulan yang diperoleh adalah program sapi potong gaduhan memberikan manfaat dalam hal peningkatan populasi, penyerapan tenaga kerja dan peningkatan pendapatan terhadap peternak di Manokwari, Papua Barat.

(Kata kunci: Program gaduhan sapi potong, Evaluasi program)

\section{ABSTRACT}

The objective of the research cattle sharing program implemented by Lembaga Mandiri yang Mengakar di Masyarakat (LM3), an independent community-based institution in Manokwari, West Papua, in terms of farmer income, labor employment and cattle population increase. A survey was conducted using all the 55 farmers participating the program from August to October, 2010. Net present value (NPV), benefit cost ratio (BCR) and internal rate of return (IRR) were determined from the conditions of before and after participating the program. NPV was found to increase for 64.40\% from IDR 18,251,432 (before) to IDR 28,338,774 (after). BCR and IRR were 21.35 and 50\% respectively. Average income was found to be IDR 5,212,500/year. Cattle natural population increase was found to be $27.05 \% / y e a r$. This program increased the labor employment as much as $12.27 \%$. Regression analysis showed that the factors affecting the ability of farmers to give back the share were cattle mortality $(P<0.01)$, farmer experience $(P<0.05)$ and calving interval $(P<0.01)$. It is concluded that this cattle sharing program is a success program in increasing cattle population, employment and income of the farmers in Manokwari, West Papua.

(Key words: Cattle-sharing program, Program evaluation)

\section{Pendahuluan}

Pembangunan peternakan sebagai bagian dari subsektor pertanian, terus diupayakan pengembangannya dalam mencukupi kebutuhan protein hewani sekaligus memberikan kontribusi yang

\footnotetext{
* Korespondensi (corresponding author):

Telp. +62 8124000 9758E-mail:

lukas.sonbait@gmail.com
}

nyata dalam pembangunan nasional. Sapi potong merupakan komoditas ternak yang potensial dikembangkan di Indonesia untuk menunjang target tersebut. Salah satu kawasan timur Indonesia yang memiliki potensi bagi pengembangan ternak sapi potong adalah Provinsi Papua Barat. Alasan utama pengembangan ternak sapi potong adalah kondisi lahan yang cukup luas serta ketersediaan hijauan ternak dan limbah pertanian yang cukup melimpah sepanjang tahun bagi kebutuhan ternak. Jenis sapi 
potong yang umumnya dipelihara adalah sapi Bali yang memiliki daya adaptasi yang cukup tinggi, konversi pakan dan daya tahan terhadap penyakit baik, dan fertilitas yang baik sekali, serta dapat digunakan sebagai ternak kerja (Bandini, 2003). Kabupaten Manokwari adalah salah satu sentra pengembangan ternak sapi potong di Papua Barat yang memiliki prospek menjanjikan untuk pengembangan usaha sapi potong. Hal ini didukung dengan tingkat konsumsi daging di Provinsi Papua Barat yang terus mengalami peningkatan.

Pada tahun 2006 konsumsi daging sapi sebanyak 1.802 ton dan meningkat menjadi 2.554 ton pada tahun 2007 atau mengalami pertumbuhan sebesar 1,41\% (FPPK UNIPA, 2008). Tindakan yang dilakukan oleh pemerintah adalah dengan melakukan pengembangan ternak untuk meningkatkan produksi dan populasinya. Pada sisi lain, penelitian lain yang dilakukan Widayati (2005), menunjukkan bahwa perkembangan ternak sapi Bali di Kabupaten Manokwari tidak mengalami peningkatan yang signifikan. Hal ini dibuktikan dengan jumlah kepemilikan ternak yang rendah yaitu hanya berkisar 2-5 ekor per keluarga per tahun. Keberhasilan usaha sapi potong dipengaruhi oleh faktor internal maupun eksternal. Faktor internal meliputi skala usaha, modal peternak dan lokasi sedangkan eksternal meliputi pasar, teknologi, kondisi ekonomi dan kebijakan pemerintah. Kondisi peternakan sapi potong di Papua Barat hampir sama dengan beberapa daerah di Indonesia yakni masih dikelola secara tradisional dan bertumpu pada usaha peternakan rakyat. Salah satu masalah internal yang paling dirasakan oleh peternak di lapangan adalah kurangnya modal dalam usaha pengembangan sapi potong. Masalah ini berdampak pada kepemilikan ternak yang rendah, tenaga kerja yang belum dimaksimalkan serta rendahnya pendapatan yang diperoleh dari usaha sapi potong. Salah satu upaya yang dilakukan oleh pemerintah daerah khususnya Kabupaten Manokwari untuk mengembangkan sapi potong adalah dengan melaksanakan program kemitraan melalui pemberdayaan ekonomi rakyat dengan pemberian bantuan sapi kepada beberapa kelompok peternak dalam bentuk sapi gaduhan. Saptana dan Ashari (2007) menyatakan bahwa kemitraan adalah suatu jalinan kerja sama berbagai pelaku agribisnis, mulai dari kegiatan praproduksi, produksi hingga pemasaran. Kemitraan dilandasi oleh azas kesetaraan kedudukan, saling membutuhkan, dan saling menguntungkan serta adanya persetujuan di antara pihak yang bermitra untuk saling berbagi biaya, resiko, dan manfaat. Pada pola kemitraan tersebut, pemerintah bertindak sebagai inti dan peternak sebagai plasma. Dalam proses produksi, peternak hanya menyediakan tenaga kerja dan kandang, sedangkan pihak pemerintah menyediakan bibit, pakan, obat-obatan, pelayanan teknik berproduksi dan kesehatan hewan (Hartono, 2000).

Salah satu kegiatan yang dilaksanakan adalah program pengembangan agribisnis peternakan yang dilakukan dalam bentuk Bantuan Pinjaman Langsung Masyarakat (BPLM) kepada kelompok tani ternak yang sifatnya bergulir dan diarahkan pada usaha pengembangan agribisnis sapi potong. Tahun 2006/2007 merupakan tahun ke enam program ini dijalankan yang pembiayaannya bersumber dari dana dekonsentrasi (APBN) sebesar Rp. 459.800.000,00 dengan DIPA nomor: 0162.0/018-06.1/-/2007; yang dialokasikan melalui program kegiatan pemberdayaan dan pengembangan agribisnis peternakan Lembaga Mandiri yang Mengakar di Masyarakat (LM3) yang ada di Manokwari (Dinas Peternakan Kabupaten Manokwari, 2008). Bantuan pemerintah dalam bentuk sistem penguatan modal usaha tersebut diberikan kepada 4 kelompok pemberdayaan dan pengembangan usaha agribisnis LM3, yaitu kelompok Ponpes Darusallam sebanyak 40 ekor sapi pada 13 peternak. Pada kelompok lainnya, masing-masing adalah kelompok Paroki St. Kristoforus sebanyak 39 ekor sapi pada 16 peternak, Klasis Hatam Moile Meach sebanyak 39 ekor sapi pada 15 peternak, dan Yayasan Lentera Hati sebanyak 22 ekor sapi kepada 11 peternak. Total ternak yang didistribusi sebanyak 140 ekor. Penyerahan bantuan ini dilakukan sesuai dengan rencana usaha kelompok (RUK). Keberhasilan dari program agribisnis bidang peternakan LM3 yang telah digulirkan diharapkan sesuai dengan tujuan utama program itu sendiri yaitu mampu mengarahkan usaha peternakan rakyat yang selama ini masih bersifat tradisional menjadi industri, menciptakan lapangan kerja, serta peningkatan pendapatan peternak. Selain itu, faktor-faktor sosial dan faktor penampilan reproduksi yang turut berpengaruh terhadap keberhasilan gaduhan sapi potong perlu dilakukan pengkajian. Sampai sejauh ini, pemerintah belum melakukan evaluasi secara menyeluruh terhadap program gaduhan, oleh karena itu peneliti tertarik untuk mengevaluasi terhadap program pengembangan sapi potong gaduhan melalui kelompok LM3 di Kabupaten Manokwari, agar dapat dipakai sebagai acuan dalam upaya perbaikan program pengembangan sapi potong di masa mendatang. Tujuan dari penelitian adalah untuk mengevaluasi kelayakan usaha dan efektifitas program pengembangan sapi potong gaduhan ditinjau dari aspek peningkatan populasi sapi potong gaduhan, penyerapan tenaga, peningkatan pendapatan peternak, serta faktor-faktor yang mempengaruhi waktu pengembalian gaduhan sapi potong. Manfaat penelitian sebagai bahan pertimbangan dalam 
menjalankan usaha sapi potong dalam rangka memanfaatkan paket gaduhan sapi potong untuk meningkatkan pendapatan usahatani, pertimbangan dalam pengambilan kebijakan terutama dalam upaya pengembangan usaha sapi potong melalui pola gaduhan kepada kelompok LM3 yang saling menguntungkan.

\section{Materi dan Metode Penelitian}

\section{Lokasi dan waktu penelitian}

Lokasi penelitian adalah di Distrik Prafi Kabupaten Manokwari, Papua Barat. Penelitian dilakukan sejak bulan Agustus sampai dengan Oktober 2010.

\section{Materi penelitian}

Materi yang digunakan dalam penelitian adalah semua peternak penerima sapi gaduhan pada tahun 2006-2008 yang tergabung dalam 4 kelompok LM3 di Distrik Prafi, Kabupaten Manokwari yaitu Ponpes Darusallam, Paroki St. Kristoforus, Klasis Hatam Moile Meach dan Yayasan Lentera Hati yang berjumlah 55 orang.

\section{Metode pengambilan data}

Pengambilan data dilakukan dengan metode sensus. Data yang diambil meliputi data primer dan sekunder. Data primer diperoleh dengan cara wawancara langsung dengan responden penerima bantuan program gaduhan sapi potong dengan berpatokan pada kuesioner yang telah disiapkan. Data sekunder diperoleh dari dinas terkait serta literatur yang berkaitan dengan penelitian.

\section{Analisis data}

Hasil penelitian berupa data lapangan, ditabulasi selanjutnya dianalisis sesuai dengan tujuan penelitian yaitu 1) peningkatan populasi, 2) peningkatan pendapatan, 3) penyerapan tenaga kerja serta faktor-faktor yang mempengaruhi waktu pengembalian. Untuk mengetahui kelayakan menggunakan metode discounted cash flow (arus kas terdiskonto) meliputi: benefit cost ratio (BCR), net present value (NPV), dan internal rate of return (IRR) (Gray et al., 2005). Untuk mengetahui faktor yang mempengaruhi waktu pengembalian gaduhan, dianalisis menggunakan model regresi linier ber- ganda (Algifari, 2000). Model matematis yang digunakan adalah: $\mathrm{Y}=\mathrm{a}=+\mathrm{b}_{1} \mathrm{X}_{1}+\mathrm{b}_{2} \mathrm{X}_{2}+\mathrm{b}_{3} \mathrm{X}_{3}+$ $\mathrm{b}_{4} \mathrm{X}_{4}+\mathrm{b}_{5} \mathrm{X}_{5}+\mathrm{e}$

Keterangan:

$\begin{array}{ll}\mathrm{Y} & =\text { waktu pengembalian (tahun) } \\ \mathrm{X}_{1} & =\text { pengalaman beternak (tahun) } \\ \mathrm{X}_{2} & =\text { alokasi tenaga kerja beternak } \\ & \text { (HOK/tahun) } \\ \mathrm{X}_{3} & =\text { jumlah tanggungan } \\ \mathrm{X}_{4} & =\text { calving interval (bulan) } \\ \mathrm{X}_{5} & =\text { angka mortalitas (\%) } \\ \mathrm{a} & =\text { konstanta atau intersep } \\ \mathrm{b}_{1}-\mathrm{b}_{5} & =\text { koefisien regresi masing-masing variabel } \\ \mathrm{e} & =\text { error }\end{array}$

\section{Hasil dan Pembahasan}

\section{Umur peternak}

Umur merupakan salah satu faktor yang berpengaruh terhadap kerja dan pola pikir peternak dalam menentukan corak dan pola manajemen yang diterapkan dalam mengelola usahatani-ternaknya. Sejalan dengan semakin meningkatnya umur, maka produktivitasnya menurun, namun semakin tinggi pula pengalaman orang tersebut (Suratiyah, 2006). Klasifikasi umur peternak gaduhan selengkapnya tersaji pada Tabel 1.

Rerata umur peternak sapi adalah 46,6 tahun dengan kisaran 32-70 tahun yang merupakan usia yang produktif sesuai dengan Mantra (1985) yang menyatakan bahwa penduduk yang termasuk dalam angkatan kerja adalah penduduk dengan umur 15-64 tahun. Kisaran umur yang telah masuk dalam angkatan kerja akan lebih mudah menerima adanya suatu inovasi, sehingga masih memungkinkan untuk mengembangkan usaha peternakan gaduhan sapi potong. Kajian yang dilakukan Fatati (2001) menunjukkan bahwa semakin muda umur seseorang maka semakin cepat menerima perubahan dari luar karena petani peternak selalu ingin mencoba sesuatu yang baru sebagai upaya untuk meningkatkan pengetahuan dan ketrampilan dalam diversifikasi usahanya.

\section{Tingkat pendidikan peternak}

Tingkat pendidikan meliputi pendidikan formal maupun non formal. Tingkat pendidikan akan sangat berpengaruh terhadap perbedaan cara

Tabel 1. Klasifikasi peternak berdasarkan umur (classification of farmers based on age)

\begin{tabular}{ccr}
\hline \hline Umur $($ age $)$ & Orang (farmers' $)$ & $(\%)$ \\
\hline $0-15$ & 0 & 0,00 \\
$15-64$ & 52 & 94,54 \\
$>64$ & 3 & 5,46 \\
Total & 55 & 100,00 \\
\hline
\end{tabular}


pikir peternak dalam mengadopsi berbagai inovasi dan teknologi yang diperolehnya, selanjutnya dapat meningkatkan produktivitas usaha peternakan. Peternak dengan tingkat pendidikan yang tinggi akan lebih cepat dalam menerima inovasi baru dibanding dengan peternak yang tingkat pendidikannya lebih rendah. Secara rinci tingkat pendidikan peternak tersaji pada Tabel 2 .

Tingkat pendidikan peternak yang terbanyak yaitu berpendidikan SD sampai dengan SMP sekitar $50 \%$. Hal ini sesuai dengan kondisi di Indonesia umumnya peternakan rakyat sebagian besar berpendidikan SMP ke bawah. Peternak yang mempunyai tingkat pendidikan yang tinggi akan lebih cepat dalam menerima dan memahami informasi baru, mampu melakukan perubahan inovatif dalam manajemen ternaknya. Soekartawi et al. (1984) menyatakan bahwa petani dengan tingkat pendidikan tinggi lebih cepat dalam melaksanakan adopsi inovasi.

\section{Pengalaman beternak}

Pengalaman beternak peserta program gaduhan ternak sapi Bali di Kabupaten Manokwari tersaji pada Tabel 3. Peternak pada umumnya mempunyai pengetahuan mengenal sapi dalam waktu yang relatif lama. Rerata pengalaman beternak 14 tahun dengan kisaran 2-45 tahun. Hal ini disebabkan ternak sapi mempunyai hubungan yang sangat erat dengan usaha pertanian, maupun sebagai tabungan keluarga, misalnya ternak dapat digunakan sebagai modal untuk menyekolahkan anak maupun sebagai modal usaha lain. Dalam upaya pengembangan gaduhan sapi potong tersebut maka peternak dibekali dengan pengetahuan praktis tentang cara beternak sapi potong melalui penyuluhan dan bimbingan langsung dari Dinas Pertanian dan Peternakan Kabupaten Manokwari. Menurut Isbandi (2004), penyuluhan dan pembinaan terhadap petani peternak dilakukan untuk mengubah cara beternak dari pola tradisional menjadi usaha ternak komersial dengan menerapkan cara-cara zooteknik yang baik.

\section{Mata pencaharian}

Mata pencaharian peternak penerima gaduhan sapi potong tersaji pada Tabel 4 . Berdasarkan Tabel 4, usaha sapi potong yang dilakukan responden masih merupakan usaha sambilan, hampir $50 \%$ responden bermata pencaharian sebagai petani. Kondisi ini terjadi karena daerah ini merupakan petani yang mengikuti

Tabel 2. Tingkat pendidikan peternak (farmers'education)

\begin{tabular}{|c|c|c|}
\hline \multirow{2}{*}{ Tingkat pendidikan (education) } & \multicolumn{2}{|c|}{ Jumlah (total) } \\
\hline & Orang (farmers') & $(\%)$ \\
\hline Tidak sekolah (illiterate) & 2 & 3,63 \\
\hline $\mathrm{SD}$ (primary school) & 17 & 30,91 \\
\hline SMP (junior high school) & 14 & 25,46 \\
\hline SMA (senior high school) & 16 & 29,10 \\
\hline D1- D3 (diploma) & 4 & 7,27 \\
\hline S1 (undergraduate) & 2 & 3,63 \\
\hline Total & 55 & 100,00 \\
\hline
\end{tabular}

Tabel 3. Pengalaman peternak peserta program (farmer's experience)

\begin{tabular}{ccc}
\hline \hline Pengalaman (tahun) (experience (year) $)$ & Orang (farmers) & $(\%)$ \\
\hline$<5$ & 12 & 21,81 \\
$5-10$ & 15 & 27,27 \\
$11-16$ & 6 & 10,90 \\
$>16$ & 22 & 40,00 \\
Total & 55 & 100,00 \\
\hline
\end{tabular}

Tabel 4. Mata pencaharian pokok peternak (main occupation of farmer)

\begin{tabular}{lcr}
\hline \hline \multicolumn{1}{c}{ Mata pencaharian (occupation) } & Orang (farmer) & $(\%)$ \\
\hline Petani (farmer) & 30 & 54,54 \\
Swasta (non farmer) & 12 & 21,82 \\
PNS (government official) & 10 & 18,19 \\
Pensiunan (retired) & 1 & 1,82 \\
Lain - lain (others) & 2 & 3,63 \\
\multicolumn{1}{c}{ Total } & 55 & 100,00 \\
\hline
\end{tabular}


program transmigrasi di daerah ini untuk meningkatkan sentra produksi pertanian di Papua Barat. Komoditas utama adalah tanaman pangan. Pada umumnya usaha peternakan adalah usaha sambilan untuk mencukupi kebutuhan hidup sendiri (Ditjen Peternakan, 1991). Hal ini sesuai dengan pendapat Roessali et al. (2005), bahwa usaha tani atau usaha ternak sapi potong rakyat umumnya berskala kecil. Tujuan utama pemeliharaan sapi di Manokwari telah bergeser dari ternak kerja yang digantikan oleh tenaga mesin (hand tractor) sehingga sampai saat ini lebih diarahkan untuk tabungan keluarga yang sewaktu-waktu dapat digunakan dalam rangka kebutuhan yang mendesak untuk dijadikan modal. Tawaf dan Kuswaryan (2006) menyatakan bahwa usaha ternak sapi potong rakyat hendaknya mulai diarahkan ke usaha komersial, bukan lagi sebagai hobi atau tabungan, karena peternakan rakyat akan menjadi tulang punggung keberhasilan program kecukupan daging di masa mendatang. Data di atas juga menunjukkan bahwa program gaduhan LM3 belum sepenuhnya tepat sasaran karena sesuai aturan peserta tidak boleh bekerja tetap, tapi kenyataannya masih ada peternak yang sudah memperoleh pekerjaan dan pendapatan tetap namun masih memperoleh gaduhan sapi. Hal ini bertentangan dengan tujuan LM3 diantaranya menciptakan lapangan kerja bagi masyarakat.

\section{Jumlah anggota keluarga peternak}

Jumlah anggota keluarga peternak dapat mempengaruhi aktivitas usaha peternak itu sendiri karena jumlah anggota keluarga dapat mensuplai ketersediaan tenaga kerja yang dapat membantu kegiatannya. Secara lengkap komposisi keluarga peternak tersaji pada Tabel 5 .
Pada Tabel 5 menjelaskan bahwa rerata jumlah anggota keluarga responden adalah 4,31 orang yang terdiri dari berbagai golongan umur. Pada umumnya berada pada usia di atas 15 tahun $(63,45 \%)$ yang merupakan usia produktif, sedangkan hanya 36,55\% merupakan tanggungan keluarga. Dilihat dari segi jumlah anggota keluarga, semakin besar jumlah anggota keluarga maka semakin besar kebutuhan keluarga yang harus dipenuhi. Dengan demikian maka akan mendorong petani berusaha memperoleh tambahan pendapatan melalui usaha lainnya. Sebagaimana terlihat pada penelitian ini bahwa salah satu tujuan pengembangan gaduhan sapi potong adalah untuk menambah pendapatan keluarga. Apabila ditinjau dari segi tenaga kerja, maka jumlah anggota keluarga menentukan ketersediaan tenaga kerja dalam kegiatan usahanya.

\section{Kepemilikan ternak}

Komposisi ternak didasarkan pada umur ternak yang terdiri dari pedet (lahir hingga umur 6 bulan), dara dan muda (umur antara 6-12 bulan), serta dewasa (lebih dari 12 bulan). Kepemilikan ternak dihitung berdasarkan unit ternak (UT) dengan menggunakan konversi sebagai berikut: satu ekor pedet $=0,5 \mathrm{UT}$, satu ekor ternak muda $=0,8$ UT dan ternak dewasa $=1$ UT (Ditjen Peternakan, 2004). Jenis sapi yang diusahakan adalah sapi Bali. Rerata kepemilikan ternak tersaji pada Tabel 6.

Berdasarkan Tabel 6, rata-rata kepemilikan ternak sapi potong adalah 2,39 UT. Rata-rata setiap peternak memiliki 3 ekor ternak yang terdiri dari 1 ekor dewasa, 1 ekor muda dan 1 ekor pedet. Rerata kepemilikan ternak merupakan sisa ternak yang ada hingga saat ini, setelah melunasi pengembalian

Tabel 5. Komposisi keluarga berdasarkan umur dan jenis kelamin (age and sex composition of family)

\begin{tabular}{|c|c|c|c|}
\hline Kelompok umur (tahun) age group (year)) & $\begin{array}{l}\text { Jenis kelamin } \\
\quad(\text { sex })\end{array}$ & $(\%)$ & $\begin{array}{c}\text { Rerata anggota keluarga (average } \\
\text { members offamily) }\end{array}$ \\
\hline \multirow[t]{2}{*}{$0-9$} & Pria (male) & 7,99 & 0,34 \\
\hline & Wanita (female) & 10,92 & 0,47 \\
\hline \multirow[t]{2}{*}{$10-14$} & Pria (male) & 8,40 & 0,36 \\
\hline & Wanita (female) & 9,24 & 0,40 \\
\hline \multirow[t]{3}{*}{$>15$} & Pria (male) & 36,55 & 1,58 \\
\hline & Wanita (female) & 26,90 & 1,16 \\
\hline & & 100,00 & 4,31 \\
\hline
\end{tabular}

Tabel 6. Rerata kepemilikan ternak (unit ternak) (average of cattle ownership (animal unit))

\begin{tabular}{lcccc}
\hline \hline \multirow{2}{*}{ Jenis kelamin $($ sex $)$} & \multicolumn{3}{c}{ Umur (bulan) (age (month) } & \multirow{2}{*}{ Total } \\
\cline { 2 - 4 } & $>12$ & $6-12$ & $<6$ & 0,85 \\
Jantan $($ male $)$ & 0,50 & 0,23 & 0,12 & 1,54 \\
Betina (female) & 1,16 & 1,20 & 0,18 & 2,39 \\
\hline \multicolumn{1}{c}{ Total } & 1,66 & 1,43 & 0,30 & \\
\hline
\end{tabular}


ternak gaduhan dan ternak yang telah dijual atau merupakan peternak berskala kecil. Hal ini didukung oleh pernyataan Roessali (2004) bahwa peternak skala kecil dalam pemeliharan sapi hanya sebagai sampingan dan cenderung mempertahankan jumlahnya agar tetap sama dari tahun ke tahun berdasarkan kemampuan jumlah anggota keluarga.

\section{Penyerapan tenaga kerja}

Berdasarkan hasil penelitian di lapangan diperoleh data bahwa tenaga kerja yang digunakan dalam kegiatan usahatani berasal dari dalam keluarga maupun dari luar keluarga. Khusus untuk usaha gaduhan sapi potong, tenaga kerja masih mengandalkan tenaga kerja dalam keluarga. Pada penelitian yang dilakukan, ketersediaan tenaga kerja keluarga dihitung berdasarkan hari kerja pria (HKP) dengan konversi: 1 orang pria dewasa $=1 \mathrm{HKP}$ dapat bekerja selama $7 \mathrm{jam} /$ hari, 1 orang wanita dewasa $=0,7 \mathrm{HKP}$ dan 1 orang anak (Umur 10-14 tahun) $=0,5$ HKP (Hermanto, 1995). Ketersediaan tenaga kerja keluarga secara keseluruhan untuk usaha pertanian dan peternakan serta usaha lainnya tersaji pada Tabel 7.

Berdasarkan Tabel 7, rata-rata jumlah anggota keluarga responden peternak yang tergolong usia kerja (usia 10-64 tahun) adalah sebanyak 3,50 orang dengan perincian 1,58 orang pria dewasa, 1,16 wanita dewasa dan 0,76 orang anak. Apabila dikonversikan berdasarkan JOK, maka jumlah jam kerja keluarga yang tersedia untuk masing-masing responden adalah 22,17 JOK, yang terdiri dari pria dewasa $12,64 \mathrm{JOK}$, wanita dewasa 6,50 JOK dan tenaga kerja anak 3,04 JOK. Ratarata penyerapan tenaga kerja untuk usaha pertanian adalah 5,26 JOK, usaha gaduhan sapi potong 1,49 JOK serta usaha lainnya adalah 3,67 JOK. Matatula (1997) menyatakan bahwa penyerapan tenaga kerja keluarga usaha sapi potong sebesar $13,85 \%$ dari total tenaga kerja produktif. Hal ini menunjukkan bahwa pada daerah penelitian penyerapan tenaga kerja untuk usaha peternakan masih rendah karena usaha peternakan masih merupakan usaha sampingan. Penyerapan tenaga kerja untuk usaha pertanian adalah $23,71 \%$ dari tenaga kerja tersedia, penyerapan tenaga kerja untuk usaha gaduhan sapi potong adalah $6,70 \%$ dari tenaga kerja tersedia serta penyerapan tenaga kerja untuk usaha lainnya $16,58 \%$ dari total tenaga kerja yang tersedia. Apabila dikonversikan pada $\mathrm{HOK} /$ tahun, maka total jam bekerja yang digunakan adalah 1011,78 jam, namun bila dikurangi dengan total $\mathrm{HOK} /$ tahun untuk usaha pertanian, gaduhan sapi potong dan usaha lainnya dalam satu tahun, masih tersisa 474,98 jam atau 11,87 JOK perhari. Berdasarkan hasil penelitian di atas menunjukkan bahwa masih tersedia tenaga kerja yang belum dimanfaatkan secara optimal, sehingga sumbangan program gaduhan sapi potong bisa menjadi salah satu solusi dalam menciptakan lapangan pekerjaan bagi masyarakat di daerah penelitian.

\section{Parameter teknis dan ekonomis sapi potong pada kondisi sekarang}

Parameter teknis dan ekonomis sapi potong pada gaduhan sapi potong saat ini yang diperoleh pada lokasi penelitian berdasarkan pengamatan adalah calving interval 13 bulan, mortalitas $1 \%$ dari rerata nilai ternak yang dipelihara. Harga jual rerata ternak sapi potong jantan adalah Rp. 9.000.000,00/ekor, induk Rp. 6.000.000,00/ekor, jantan muda Rp. 4.500.000,00/ekor, betina muda Rp. 4.000.000,00/ ekor, sedangkan untuk pedet ratarata per ekor adalah Rp. 1.500.000,00. Proyeksi model usaha sapi potong dengan pemberian gaduhan 2 ekor induk yang siap dikawinkan, dengan pengembalian 2 ekor turunan umur 12-16 bulan, jangka waktu 4 tahun dan calving interval 13 bulan, memperlihatkan bahwa pada tahun ketiga peternak dapat mengembalikan pinjaman yang diberikan dan dapat meningkatkan populasi ternak sapi sebanyak 2-3 ekor keturunan.

\section{Natural increase}

Natural increase dalam persen atau kenaikan populasi secara alami dihitung berdasarkan \% kelahiran dikurangi \% kematian dalam satu tahun. Pada penelitian yang dilakukan, NI dihitung sejak bulan September 2009 hingga September 2010. Tabel 8 menyajikan komposisi ternak sapi potong dan rerata umur yang diperoleh dalam penelitian.

Jumlah kelahiran pedet selama 1 tahun adalah 34 ekor atau 53,12\% dari populasi induk yaitu 64 ekor. Kematian pedet saat dilahirkan adalah 1 ekor, sehingga panen pedet (calf crop) yang diperoleh selama 1 tahun adalah 33 ekor pedet atau 51,56\% dari populasi induk. Persentase induk adalah $64 / 122$ $\mathrm{X} 100 \%=52,45 \%$, sehingga persentase kelahiran pedet per populasi total adalah $53,12 \% \times 52,45 \%=$ $27,86 \%$. Jumlah kematian sapi potong dari populasi selama 1 tahun adalah 1 ekor atau $1 / 122 \times 100 \%=$ $0,81 \%$. Berdasarkan hasil tersebut maka angka NI dari usaha gaduhan sapi potong LM3 pada penelitian ini adalah $27,86 \%-0,81 \%=27,05 \%$ setahun. Bila dibandingkan dengan peternak bukan pengaduh, dari 216 ekor ternak yang diambil sebagai acak di lokasi penelitian, angka NI yang diperoleh adalah 25,81\%. Hal ini menunjukkan dengan adanya program gaduhan dapat meningkatkan kenaikan populasi secara alami lebih baik dari peternak bukan pengaduh, walaupun tidak signifikan karena pada umumnya tatalaksana 
Tabel 7. Penyerapan tenaga kerja keluarga untuk usaha pertanian, peternakan dan usaha lain (absorbtion of family labour to the effort agriculture, ranch and other effort)

\begin{tabular}{cccccr}
\hline \hline Umur (tahun) (age (year)) & $\begin{array}{c}\text { Rerata jumlah } \\
\text { orang (average } \\
\text { family number) }\end{array}$ & $\begin{array}{c}\text { Setara pria } \\
\text { dewasa (man } \\
\text { equivalent) }\end{array}$ & $\begin{array}{c}\text { JOK/hari (working } \\
\text { hours/day) }\end{array}$ & $\begin{array}{c}\text { HOK/tahun } \\
\text { (working } \\
\text { days/year) }\end{array}$ & $\%$ \\
\hline$>14$ pria (adult male) & 1,58 & 1,58 & 12,64 & 576,70 & 57,00 \\
$>14$ wanita (adult female) & 1,16 & 0,81 & 6,50 & 296,38 & 29,30 \\
$14-16$ anak (children) & 0,76 & 0,38 & 3,04 & 138,70 & 13,70 \\
Total & 3,50 & 4,02 & 22,17 & $1,011,78$ & 100,00 \\
\hline
\end{tabular}

Tabel 8. Natural increase ternak sapi potong pada peternak peserta program (natural increase of the catlle belong to the farmer)

\begin{tabular}{|c|c|c|c|c|c|}
\hline \multirow{2}{*}{$\begin{array}{l}\text { Kriteria umur (tahun) } \\
\text { (age group (years)) }\end{array}$} & \multicolumn{2}{|c|}{ Jantan (male) } & \multicolumn{2}{|c|}{ Betina (female) } & \multirow{2}{*}{ Total } \\
\hline & Ekor (head) & Rerata (average) & Ekor (head) & Rerata (average) & \\
\hline$>12$ & 28 & 2,28 & 64 & 3,24 & 92 \\
\hline $6-12$ & 16 & 1,8 & 14 & 1,9 & 30 \\
\hline$<6$ & 14 & 0,45 & 20 & 0,46 & 34 \\
\hline Total & 58 & & 98 & & 156 \\
\hline
\end{tabular}

pemeliharaan ternak relatif sama antara peternak pengaduh dan bukan pengaduh di daerah penelitian. Apabila dilihat dari angka NI sapi di lokasi penelitian termasuk tinggi bila dibandingkan dengan angka NI Indonesia tahun 1991 sebesar 17,5\% (Fakultas Peternakan UGM, 1991). Tingginya angka NI disebabkan karena jarak beranak (calving interval) yang ideal yaitu 13 bulan, serta peternak gaduhan sudah mengetahui kapan ternak akan dikawinkan sehingga waktu perkawinan dapat berlangsung dengan baik.

\section{Analisis finansial usaha gaduhan sapi potong}

Dalam analisis finansial yang terutama dilakukan adalah mengetahui apakah usaha yang dijalankan dalam jangka waktu tertentu dapat memberikan keuntungan atau tidak bagi peternak gaduhan sapi potong. Berdasarkan hasil analisis finansial with and without proyek gaduhan sapi potong menunjukkan pendapatan petani sebelum adanya proyek diperoleh dari usaha pertanian secara umum adalah Rp. 6.009.000,00/tahun. Pada tahun pertama sampai dengan tahun kedua usaha gaduhan sapi potong secara finansial belum menghasilkan pendapatan, dimana usaha gaduhan sapi potong belum menghasilkan keturunan atau pedet yang dilahirkan untuk membayar angsuran. Dalam periode proyek tahun ketiga dan keempat usaha gaduhan sapi potong secara finansial mampu memberikan peningkatan pendapatan selama 4 tahun masingmasing sebesar Rp. 3.100.000,00 dan Rp. 14.900.000,00. Untuk mengetahui kelayakan usaha yang dijalankan, maka digunakan tiga kriteria kelayakan yaitu BCR, NPV, dan IRR dengan menggunakan discount rate $12 \%$ dan jangka waktu 4 tahun pada saat penelitian, dimana program proyek gaduhan sapi potong dari Dinas Pertanian, Peternakan dan Perkebunan Kabupaten Manokwari berkisar 3-5 tahun.

\section{Benefit cost ratio (BCR)}

Benefit cost ratio merupakan perbandingan antara hasil yang di present value-kan dengan biaya modal sebagai indikator bias diterima atau tidaknya suatu investasi yang dijalankan. Menurut Machfoedz (1987), kriteria BCR memberikan pedoman bahwa proyek akan dipilih apabila BCR lebih besar dari 1, juga sebaliknya bila suatu proyek mempunyai BCR lebih kecil dari 1 maka proyek tidak akan dipilih. Dalam penelitian ini BCR dihitung berdasarkan lama usaha sejak petani memperoleh gaduhan sapi potong hingga saat penelitian dilaksanakan. Pada program gaduhan yang dilaksanakan sebagian besar input yang digunakan oleh peternak diantaranya; tenaga kerja, kandang, pakan dan obat-obatan untuk memelihara ternak tidak mengeluarkan biaya. Dalam hal ini peternak tidak mengeluarkan kas untuk investasi sapi. Peternak pada dasarnya hanya memanfaatkan keuntungan hasil penggemukan penjualan anak ternak. Nilai BCR sebesar 21,35 menunjukkan bahwa usaha gaduhan sapi layak untuk dijalankan karena peternak penggaduh mendapat keuntungan dari sapi yang dipeliharanya.

\section{Net present value (NPV)}

Net present value merupakan keseluruhan dari aliran net cash flow yang digandakan dengan discount factor pada tahun dan tingkat bunga dengan rate yang telah ditentukan (Gray et al., 2005). Pada penelitian yang dilakukan menggunakan tingkat bunga sebesar $12 \%$. Hal ini mengacu 
pada tingkat diskonto yang digunakan di Indonesia. Menurut Gray et al. (2005), tingkat diskonto berkisar antara 10-15\%. Sesuai dengan asumsi bahwa sejumlah uang tertentu pada saat sekarang mempunyai nilai yang berbeda pada saat yang akan datang maka kriteria dari NPV membantu dalam mengetahui berapa nilai rupiah yang diterima pada saat ini dan jika diterima pada waktu yang akan datang. Berdasarkan hasil penelitian usaha gaduhan sapi potong selama 4 tahun mempunyai NPV positif atau lebih besar dari nol yaitu Rp. 28.338.774,00. Hal ini menunjukkan bahwa usaha ini layak dijalankan (feasible). Hal ini didukung oleh Kadariah et al. (1999) dimana suatu proyek jika perhitungan NPV lebih besar dari 0 (nol) maka usaha/proyek tersebut layak dijalankan dan jika NPV lebih kecil dari 0 (nol) tidak layak untuk dilaksanakan karena masih ada penggunaan lain yang lebih menguntungkan untuk sumber-sumber yang diperlukan proyek. Selanjutnya apabila NPV sama dengan 0 (nol) berarti proyek tersebut dalam keadaan break event point (BEP).

\section{Internal rate of return (IRR)}

Internal rate of return merupakan tingkat keuntungan dari investasi yang ditanamkan pada suatu usaha. Tujuan utama dari IRR adalah untuk mengetahui seberapa besar dana dalam suatu usaha yang direncanakan memungkinkan usaha tersebut dapat menutup balik modal dan bunga yang dikeluarkan (Jakfar dan Kashmir, 2007). Pada umumnya kriteria investasi IRR sebagai tuntunan bahwa proyek akan dipilih apabila IRR > discount rate. Menurut Gray et al. (2005), suatu proyek layak dijalankan apabila IRR lebih besar dari tingkat diskonto atau bunga pinjaman bank (10-20\%), jika lebih kecil maka investasi ditolak. Pada penelitian ini IRR lebih dari 50\%. Hal ini menunjukkan bahwa usaha gaduhan sapi layak dilanjutkan karena IRR lebih besar dari bunga pinjaman bank. Penyebab tingginya IRR dalam proyek ini adalah penggunaan faktor-faktor produksi yang rendah serta hampir $80 \%$ dari hasil investasi diperoleh dari biaya pinjaman. Analisis IRR dalam penelitian ini hanya berlaku selama 4 tahun pemeliharaan. Secara umum umur ekonomis dan teknis usaha yang dijalankan belum berakhir sehingga masa recover terhadap modal investasi tidak diperhitungkan dalam penelitian.

Faktor-faktor yang mempengaruhi waktu pengambilan gaduhan sapi potong LM3 di Kabupaten Manokwari

Untuk mengetahui faktor-faktor yang mempengaruhi lama waktu pengambilan sapi potong gaduhan LM3 maka dilakukan uji dengan meng- gunakan analisis linier berganda. Secara lengkap tersaji pada Tabel 9.

Hasil penelitian berdasarkan hasil analisis maka dirumuskan model persamaan regresi linear berganda dengan bentuk sebagai berikut:

$Y=0.777-0.019 X_{1}+0,023 X_{2}-0,026 X_{3}+0,176 X_{4}+0,060 X_{5}$

Dalam penelitian ini, waktu pengembalian sapi potong sebagai faktor dependen variabel dipengaruhi oleh beberapa faktor diantaranya adalah pengalaman beternak $\left(\mathrm{X}_{1}\right)$, alokasi tenaga kerja $\left(\mathrm{X}_{2}\right)$, jumlah tanggungan $\left(\mathrm{X}_{3}\right)$, calving interval $\left(\mathrm{X}_{4}\right)$ dan mortalitas $\left(\mathrm{X}_{5}\right)$. Hasil olahan data pada Tabel 9, variabel independen yang menunjukkan pengaruh yang signifikan terhadap waktu pengembalian sapi potong sebagai variabel dependen adalah angka mortalitas, sedangkan variabel-variabel independen yang menunjukkan pengaruh tidak signifikan adalah tenaga kerja dan jumlah tanggungan. Berdasarkan uji t, secara parsial variabel independen calving interval dan angka mortalitas diperoleh koefisien regresi bernilai positif sehingga berpengaruh signifikan terhadap variabel dependen, karena semakin pendek jarak beranak, semakin cepat waktu pengembalian ternak. Devendra et al. (1973) melaporkan bahwa jarak beranak atau calving interval sapi Bali cukup pendek yaitu 14,47 bulan.

Angka mortalitas $(\mathrm{P}<0,001)$ terhadap waktu pengembalian gaduhan sapi potong dengan nilai koefisien positif $(0,060)$ menunjukkan semakin tinggi angka mortalitas ternak maka akan semakin lama waktu pengembalian ternak gaduhan, dan sebaliknya semakin rendah angka mortalitas, semakin cepat waktu pengembalian ternak. Pada pengalaman beternak dan jumlah tanggungan diperoleh nilai koefisien regresi negatif dan berpengaruh secara signifikan terhadap variabel dependen. Pengalaman beternak $(\mathrm{P}<0,01)$ terhadap waktu pengembalian sapi potong dengan nilai koefisien regresi negatif $(-0,019)$, ini berarti semakin lama pengalaman beternak, maka semakin cepat waktu pengembalian gaduhan, dan sebaliknya semakin sedikit pengalaman beternak semakin lama waktu pengembalian ternak gaduhan. Jumlah tanggungan keluarga tidak berpengaruh terhadap waktu pengembalian karena pada daerah penelitian merupakan lokasi pertanian maupun areal perkebunan kelapa sawit, sehingga tidak semua keluarga terlibat dalam usaha ternak. Tabel 9 juga menunjukkan nilai koefisien determinasi $\left(\mathrm{R}^{2}\right)$ sebesar 0,700 artinya bahwa variasi waktu pengembalian sebagai variabel dependen dapat dijelaskan oleh variasi variabel-variabel independen dalam model persamaan regresi sebesar $70,0 \%$, sedangkan sisanya sebesar $30,0 \%$ dijelaskan oleh variasi variabel yang tidak dimasukkan dalam 
Tabel 9. Analisis regresi variabel yang mempengaruhi waktu pengembalian sapi gaduhan (regression analysis of variables affecting period of catlle restitution)

\begin{tabular}{lrrc}
\hline \hline \multicolumn{1}{c}{ Variabel independen (independent variable) } & $\begin{array}{c}\text { Koefisien regresi } \\
\text { (coefisient of } \\
\text { regression) }\end{array}$ & $\mathrm{t}$ & $\begin{array}{c}\text { Signifikan } \\
\text { (significancy) }\end{array}$ \\
\hline Constant & 0,777 & 0,713 & 0,479 \\
Pengalaman beternak (tahun) (farming experience (year)) & $-0,019$ & $-3,109$ & $0,003^{* * *}$ \\
Alokasi tenaga kerja (HOK/thn) (manpower allocation (HOK/year)) & 0,023 & 0,892 & $0,377^{\mathrm{ns}}$ \\
Jumlah tanggungan (orang) (member of dependent (person)) & $-0,026$ & $-0,555$ & $0,581^{\mathrm{ns}}$ \\
Calving interval (bulan) (calving interval (month)) & 0,176 & 2,029 & $0,048^{*}$ \\
Angka mortalitas (mortality rate) & 0,060 & 7,129 & $0,000^{* * *}$ \\
\hline Koefisien determinasi $\left(\mathrm{R}^{2}\right)=0,700$ & & & \\
$F_{\text {-hitung }}=22,840$ & & & $0,000^{* *}$ \\
\hline$* * \mathrm{P}<0,01, * * \mathrm{P}<0,05, * \mathrm{P}<0,10,{ }^{n \mathrm{~s}}$ non significant. & & &
\end{tabular}

model persamaan regresi. Nilai $F$-hitung diperoleh sebesar 22,840 $(\mathrm{P}<0,01)$, hal ini menunjukkan bahwa semua variasi variabel-variabel independen $\left(\mathrm{X}_{1}, \mathrm{X}_{2}, \mathrm{X}_{3} \ldots \ldots \mathrm{X}_{5}\right)$ dalam model persamaan regresi secara bersama berpengaruh terhadap variabel dependen.

\section{Kesimpulan dan Saran}

\section{Kesimpulan}

Dari hasil penelitian disimpulkan bahwa program pengembangan sapi potong gaduhan melalui kelompok LM3 di Kabupaten Manokwari secara umum belum mencapai target program. Hal ini dibuktikan dengan masih rendahnya peningkatan populasi ternak gaduhan, penyeleksian calon penerima belum sesuai persyaratan, adanya pelanggaran tanpa sanksi yang tegas, kurang efektifnya petugas lapangan serta masih rendahnya peternak melunasi sapi gaduhan tepat pada waktu. Hasil analisis finansial usahatani pada kondisi peternak gaduhan sapi potong pada kelompok LM3 di Kabupaten Manokwari dengan jangka waktu 4 tahun, luas lahan pertanian 43 ha dan rata-rata pemeliharaan 2 ekor sapi induk maka diperoleh nilai BCR lebih besar dari 1 yaitu 21,35, nilai NPV dengan discount rate $12 \%$ yang positif yaitu $\mathrm{Rp}$. 28.338.774,00 dan nilai IRR lebih besar dari discount factor yaitu 50\%. Rata-rata peningkatan pendapatan per tahun penerima gaduhan adalah $\mathrm{Rp}$. 5.212.500,00. Kenaikan populasi secara alami usaha gaduhan sapi potong LM3 di Kabupaten Manokwari adalah $27,05 \%$ setahun. Hasil analisis regresi menunjukkan bahwa calving interval dan angka mortalitas berpengaruh positif terhadap waktu pengembalian gaduhan sapi potong.

\section{Saran}

Usaha sapi potong gaduhan LM3 di Kabupaten Manokwari layak untuk dikembangkan dalam rangka meningkatkan pendapatan penggaduh sapi potong dan ketersediaan tenaga kerja keluarga dan tidak menutup kemungkinan untuk menambah jumlah ternak sapi yang dipelihara peternak, sehingga peranan aktif pemberi gaduhan atau kredit tidak terbatas pada pengguliran dan mengambil kredit ternak sapi gaduhan, namun perlu berperan dalam pembinaan dan pendampingan yang berkesinambungan. Selain itu, seleksi kepada penerima gaduhan harus lebih ketat serta ternak gaduhan yang didistribusi harus sesuai dengan spesifikasi serta penegakan aturan dan penerapan sanksi harus lebih tegas sesuai dengan surat perjanjian gaduhan.

\section{Daftar Pustaka}

Algifari. 2000. Analisis Regresi (Teori, Kasus dan Solusi Edisi 2). BPFE, Yogyakarta.

Bandini, Y. 2003. Sapi Bali. Penebar Swadaya, Jakarta.

Devendra, C.T., L.K. Cho, M. Pathmasingan. 1973. The productivity of Bali catle in Malays. Agric. J. 8(4): 49-55.

Dinas Peternakan Kabupaten Manokwari. 2008. Laporan Tahunan, Manokwari.

Ditjen Peternakan. 1991. Pembangunan dan pengembangan peternakan di Indonesia ditinjau dari segi perbaikan mutu genetis. Makalah. Disampaikan pada seminar sehari Pemuliaan Ternak, Bogor.

Ditjen Peternakan. 2004. Buletin Statistik Peternakan 06 - 07/VII. Departemen Pertanian RI, Jakarta.

FPPK UNIPA. 2008. Monitoring dan Evaluasi Pembangunan Peternakan Provinsi Papua Barat. Manokwari: Kerjasama FPPK UNIPA dan Dinas Pertanian Peternakan dan ketahanan Pangan Provinsi Papua Barat. Manokwari.

Fakultas Peternakan UGM. 1991. Inventarisasi potensi supply ternak potong di Jawa Tengah. 
Laporan Penelitian. Kerjasama Dengan Dinas Peternakan Daerah Tingkat I Jawa tengah.

Fatati. 2001. Perilaku petani peternak dalam diversifikasi tanaman kelapa sawit dengan sapi potong di daerah transmigrasi Sungai Bahar Kabupaten Muaro. Jurnal Ilmu - Ilmu Peternakan 4(2): 29-35.

Gray, C., P. Simanjuntak, L.K. Sabur, F.P.L. Maspaitela. 2005. Pengantar Evaluasi Proyek. Gramedia Pustaka Utama, Jakarta.

Hartono, R. 2000. Minimisasi biaya produksi usaha ternak ayam broiler dalam pola kemitraan. Buletin Peternakan 24(4): 170-175.

Hermanto, F. 1995. Ilmu Usahatani. Cetakan V. Penerbit Swadaya, Jakarta.

Isbandi. 2004. Pengaruh dinamika kelompok terhadap penerapan zooteknik oleh kelompok petani-ternak sapi potong. Jurnal Pengembangan Penyuluhan Pertanian Bidang Ilmu-Ilmu Peternakan 13: 120-123.

Jakfar dan Kasmir. 2007. Studi Kelayakan Bisnis. Edisi ke-2. Kencana, Jakarta.

Kadariah, L. Karlina, dan C. Gray. 1999. Pengantar Evaluasi Proyek. Fakultas Ekonomi. Universitas Indonesia, Jakarta.

Machfoedz, M. 1987. Akutansi Manajemen. Universitas Terbuka. Departemen Pendidikan dan Kebudayaan, Jakarta.

Mantra, I.B. 1985. Pengantar Studi Demografi. Nurcahaya, Yogyakarta.

Matatula, J.M. 1997. Evaluasi pengembangan sapi potong gaduhan yayasan mitra mandiri di daerah transmigrasi Wayapo Kab. Maluku Tengah. Tesis. Program Pascasarjana Universitas Gadjah Mada, Yogyakarta.
Roessali, W. 2004. Profitabilitas usaha pembibitan Simental di Kecamatan IV Candung Kabupaten Agam. Jurnal Pengembangan Peternakan Tropis. Spesial Edition Seminar Nasional Ruminansia 7 Oktober 2004 Buku 3. Fakultas Peternakan Universitas Diponegoro, Semarang.

Roessali, W., B.T. Eddy, dan A. Murthado. 2005. Upaya pengembangan usaha sapi potong melalui entinitas agribisnis "Corporate Farming" di Kabupaten Grobogan. Jurnal Sosial Ekonomi Peternakan 1(1): 25-30.

Saptana dan Ashari. 2007. Pembangunan pertanian berkelanjutan melalui kemitraan usaha. Jurnal Penelitian dan Pengembangan Pertanian 26(4): 126-130.

Soekartawi, A. Soehardjo, J.R. Dillon, dan B. Hardeker. 1984. Ilmu Usahatani dan Penelitian untuk Pengembangan Peternakan Kecil. Penerbit UI Press, Jakarta.

Suratiyah, K. 2006. Ilmu Usahatani. Penebar Swadaya, Jakarta.

Tawaf, R. dan S. Kuswaryan. 2006. Kendala kecukupan daging 2010. Dalam B. Suryanto, Isbandi, B.S. Mulayatno, B. Sukamto, E. Rianto, dan A.M. Legowo (ed.). Pemberdayaan Masyarakat Peternakan di Bidang Agribisnis untuk Mendukung Ketahanan Pangan. Prosiding Seminar Nasional 2006, Universitas Diponegoro, Semarang. hlm. 173-185.

Widayati, W.T. 2005. Analisis Sistem Agribisnis Sapi Potong di Provinsi Irian Jaya Barat. Universitas Negeri Papua, Manokwari. 